\title{
CULTURAL HISTORICAL ACTIVITY THEORY: EXPLORING PRINCIPALS' INSTRUCTIONAL LEADERSHIP
}

\author{
Fulya Damla Kentli ${ }^{1}$
}

\begin{abstract}
Instructional leadership activities are significant for school development. Although many researchers in this field consider leadership activities relating to the work of school principals, in effect, leadership is a network activity that includes all school staff. This study aims to show this interdependence network activity within Cultural Historical Activity Theory. The research question is "what are the activities of an instructional leader?" in order to understand instructional leadership activities in school from perspectives of Turkish graduate students and Cultural Historical Activity Theory. The answers are conceptualized within the framework of an Activity Theory. The students were asked to write about the activities of an instructional leader in the first and last course of the semester. Eighteen graduate students participated in this study.
\end{abstract}

UDC Classification: 378, DOI: http://dx.doi.org/10.12955/cbup.v4.770

Keywords: Cultural Historical Activity Theory, instructional leadership, principals.

\section{Introduction}

This study aims to use Cultural Historical Activity Theory (CHAT) to represent how instructional leadership activities might be examined in educational settings. The instructional activities have previously been scrutinized in dimensions of defining the schools' mission, managing the instructional program, and promoting a positive school climate (Hallinger \& Murphy, 1985).

\section{Literature Review}

The concept of instructional leadership has been prominent in the last three decades. The principal, as the instructional leader, has been related to curriculum and instruction that guide teachers to improve their instructional activities. There are various definitions for instructional leadership that comprises the behaviors that directly influence the curriculum, teacher instruction, and staff development (Leithwood, 1994). In one definition, instructional leadership is defined by observable practices and behaviors that principals implement (Hallinger \& Murphy, 1985; Hallinger, 2005). Hallinger and Murphy (1985) developed dimensions that enable researchers to create a perspective in analyzing instructional leadership of principals in this field. Moreover, these dimensions are related to human behavior, which may be scrutinized in the Activity Theory (Vygotsky, 1978; Engeström, 1987). In this study, three dimensions will be examined within the framework of CHAT (Engeström, 1999; Cole \& Engeström, 2007). This theory has been rapidly assimilated in educational studies (Ellis, Edwards, \& Smagorinsky, 2010; Oswald \& Engelbrecht, 2013; Wilson, 2014).

Instructional leadership is not a static, but rather a continuous meaningful activity. To study instructional leadership activity, it is essential to observe school principals within a conceptual framework to understand the inner forces of instructional leadership activities (Nohria \& Eccles, 1992). This study aims to develop a conceptual framework for examining instructional leadership activities of principals relating to instructional leadership dimensions of Hallinger and Murphy (1985) pertaining to CHAT.

\section{Data and Methodology}

Eighteen graduate students (10 girls and 8 boys), 11 teachers, and seven principals were invited to write a perspective on their instructional leadership activities. Data collection took 25 to 30 minutes overall. All writing papers were digitized by the researcher prior to analysis (Bogdan \& Biklen, 1998). The participants' statements were shown with quotations and labelled: P1, P2, P3....

The data collected pertained to structures within CHAT: subject, object, outcome, mediating artifacts, rules, community, and division of labor, as shown in Figures 1 and 2.

\footnotetext{
${ }^{1}$ Fulya Damla Kentli, Faculty of Atatürk Education, Department of Educational Sciences, Marmara University, Istanbul, Turkey, fulya.kentli@marmara.edu.tr
} 


\section{Results}

The perspectives of participants were divided into two: before and after attending graduate course for "Instructional Leadership". At the beginning of the course, the participants mainly declared seminars for teachers as the activities for instructional leadership. All participants, apart from one, noted seminars as an activity for teachers. That is, they perceived that 'instructional leadership' was related to the seminars for teachers. Secondly, participants indicated that teachers' meetings with principals was an instructional leadership activity.

Figure 1: Instructional leadership activity system-initial position

Mediating Artefacts

Seminars for teachers, teachers' meeting with principals

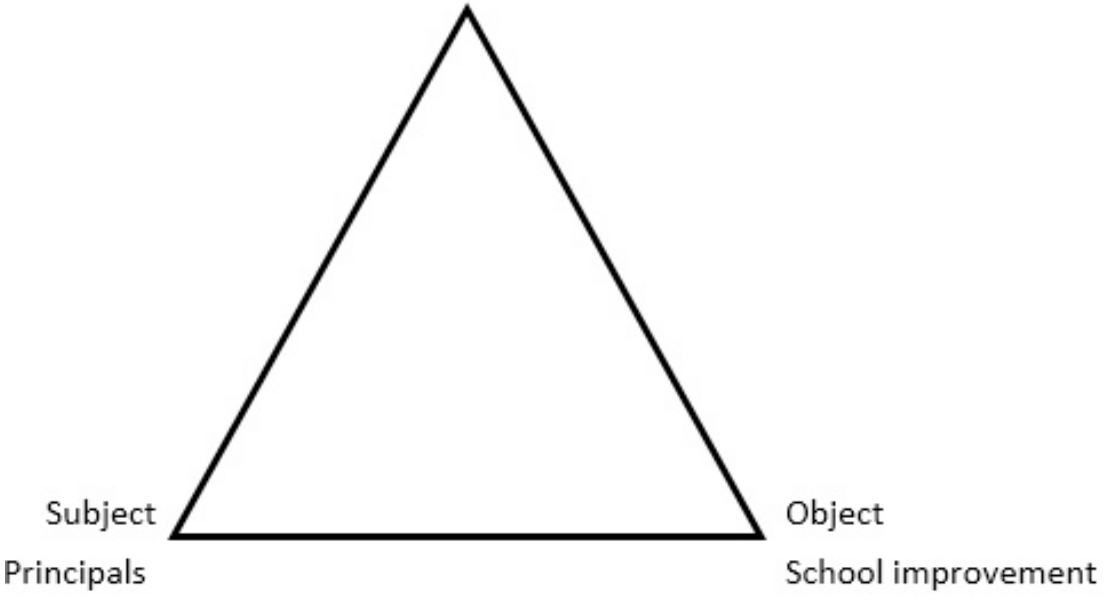

Source: Author

Thus, the participants defined the instructional leadership activities in the context of principals' tasks. The results showed that school principals were regarded as instructional leaders of the schools. In addition, their main object was to manage their staff. For that reason, they conducted seminars for teachers and meetings with teachers before starting the "instructional leadership" course, as shown in Figure 1. Statements of the participants were as follows:

P.1: "We participate in seminars for teachers. And sometimes, we have meeting with our principal."

P5: "Our principal and his directors participate in all tasks actively. Our staff has been guided in terms of their abilities and interests. We want them to produce original works."

P7: "I'm a fresh teacher for just three months. Experienced teachers in our school give me some advises. We have seminars for our fields per month. Also, our administration enables us to attend master programs in our field."

P8: "We have seminars to improve ourselves in our field per month. We read a common book and discuss on it every month."

P11: "Academic improvement, learning common societal rules, and all activities for self-actualizing of their staff. This is what I understand the concept of instructional leadership. Teacher is an instructional leader in his/her classroom; principal is an instructional leader for his/her teachers and other staff in the school."

P13: "Instructional leadership is a kind of behaviors shown by either principals or teachers to improve school's achievement and wealth. An instructional leader should be a role-model, observe teachers and other staff and give feedbacks. The principal should supply the shortages of the school as soon as possible. The principal also should explain the vision and mission of the school to his/her staff and enable them to practice."

P14: "The instructional leader is both teaching and learning person who create a positive environment in the school." 
At the end of the semester, the study was repeated, with results showing that after the Educational Leadership course, the participants' perspectives on instructional leadership had changed. This time, they insisted on a network being involved with instructional leadership. This network consisted of subject, object, mediating artefacts, rules, communities, and division of labor, as described in Figure 2. The content of the object and mediating artefacts changed, while the subject remained the same.

Therefore, more was realized than the initial three indicators (Figure 1) throughout the instructional leadership. Statements of the participants were as follows:

P.1: "Instructional leadership is responsible all educational activities in the school. Principal as an instructional leadership supervise his/her teachers' educational activities and give feedbacks. Teachers as an instructional leader should accomplish the curriculum in order to achieve students' success."

P5: "Principal and his directors should involve in all educational activities in the school in order to provide school achievement. This event should be correlated with teachers."

Figure 2: The instructional leadership activity system, final position

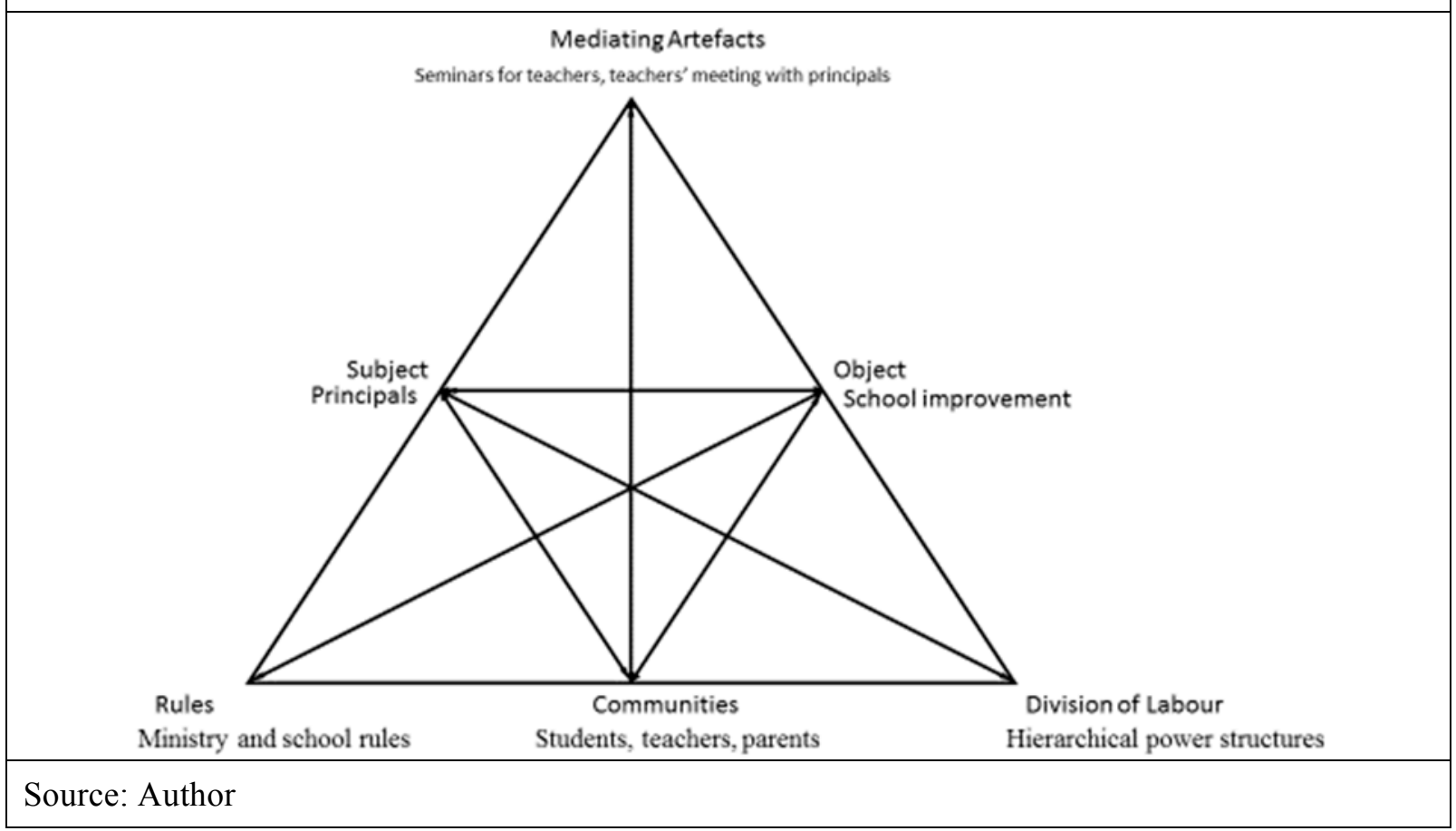

P7: "As I indicated in my previous statements, I'm a fresh teacher for just three months. Our school administration guided us to become an instructional leader within their instructional leadership activities. But after this course, what I understood that there should be hierarchical power structures in the school managed by rules. Also parents should be involved in this process."

P8: "In order to achieve school success, a principal should be an instructional leader. The concept of instructional leadership should be fulfilled by concrete event. In Turkey, we have a central educational system and it has its own rules. But a school administration should have its own rules for school success. Before this, the school administration should accept that there is a community in the school comprising of teachers, students, parents, and another staff. The administration should apply these power structures into practice very smoothly. Otherwise, it would be difficult to encounter any instructional leadership activities."

P11: "What I understood the concept of instructional leadership is managing concrete educational activities of principals for school achievement. The main target of the concept goes beyond the theory but practice. Introducing school vision and mission to all staff and enable them to practice. Giving feedback and achieve the optimum school success within the collaboration of teachers, students, parents, and another staff." 
P13: "As I indicated in my former writing that an instructional leader principal should observe teachers and other staff and give feedbacks. This explanation is right but not enough. Before observing teachers, the principal reveal his/her school vision and mission, and then make the staff acknowledged about it. Then go ahead. Planning should be done step by step. Otherwise, it is difficult to become instructional leadership activities in the school.

P14: "The instructional leader is the one who has a vision. But the difficult question is "how can we produce a vision?' what I understood after this course that even producing a vision needs a planning according to school life; namely, teachers, students, parents and another staff. And it has its own rules and relations. Therefore, it is not true that starting to become an instructional leadership by introducing your targets but being acquainted with the basement of the school.

The above statements of participants specified that their perceptions of instructional leadership noticeably changed after attending the graduate course "instructional leadership". They defined the term within the context of the school's mission, instructional program, and a positive school climate at the end of the semester. In addition, they added rules, communities, and division of labor to the system, indicating that these activities could be achieved with the help of the community (parents, teachers, and other staff) to construct a regulated learning environment. To achieve these activities there should be a hierarchical power structure administered by the school principal.

\section{Discussion}

One of the most significant findings of this study was that instructional leadership was not an individual activity but rather one involving a network. Although instructional leadership has generally been related to the role of the school principal in various studies, a network of leadership activities extends beyond the limits of the principal. This study revealed such a network in two parts. First, implementing the Activity Theory provided a framework for understanding the totality of instructional leadership activities at the beginning of the course. Second, participants shared their perspectives by taking into account the work of Hallinger and Murphy (1985) in instructional leadership dimensions. In this context, their perspectives were evaluated within the CHAT, in which instructional leadership is a mutual dependency among school staff. In this view, leadership is understood "as a matter of actions and processes" rather than exclusively as a matter of structures, states, roles, and designs (Nohria \& Eccles, 1992). As in the study of Harris (2010), the process should involve creating new teams and distributing leadership more widely for successful outcomes. Therefore, CHAT was useful in this research for identifying the whole activity system.

\section{Conclusion}

In summary, the participants appeared unfamiliar with the concept of instructional leadership at the beginning of the graduate course, whereas at the end of the course, the concept had been appreciated. Earlier appreciation would seemingly have benefited the roles of the principals and teachers who participated. Limited acquaintance with the content of this concept potentially hampers scholarly success in Turkey. Therefore, researchers, administers, academicians in this field should consider implementing projects to improve their awareness on instructional leadership.

\section{Acknowledgments}

This study was supported by the Marmara University Scientific Research Projects Committee (BAPKO).

\section{References}

Bogdan, R. C., \& Biklen, S. K. (1998). Qualitative research in education: An introduction to theory and methods (3rd ed.). Needham Heights, MA: Allyn \& Bacon.

Cole, M., \& Engeström, Y. (2007). Cultural-historical approaches to designing for development, in J. Valsiner and A. Rosa (eds), The Cambridge Handbook of Sociocultural Psychology. Cambridge: Cambridge University Press.

Ellis, V., Edwards, A., \& Smagorinsky, P. (Eds.). (2010). Cultural-historical perspectives on teacher education and development: learning teaching. London: Routledge.

Engeström, Y. (1987). Learning by Expanding: An activity theoretical approach to developmental research. Helsinki: Orienta-Konsultit.

Engeström, Y. (1999) Expansive visibilization of work: An activity-theoretical perspective. Computer Supported Cooperative Work, 8, 63-93. DOI: 10.1023/A:1008648532192 
Hallinger, P. (2005). Instructional leadership and the school principal: a passing fancy that refuses to fade away. Leadership and Policy in Schools, 4(3), 221-39. DOI: 10.1080/15700760500244793

Hallinger, P., Murphy, J. (1985). Assessing the instructional management behavior of principals. Elementary School Journal, 86(2), 217-247.

Harris, A. (2010). Distributed leadership, in Bush, T., Bell, L. and Middlewood, D. (Eds.), The Principles of Educational Leadership and Management, London, Sage.

Leithwood, K. (1994). Leadership for school restructuring. Educational Administration Quarterly, 30(4), 498-518. DOI: $10.1177 / 0013161$ X94030004006

Nohria, N., \& Eccles, R. (1992). Networks and organizations: Structure, form, and action, (pp. 288-308). Harvard Business School Press.

Oswald, M., \& Engelbrecht, P. (2013). Leadership in Disadvantaged Primary Schools: Two Narratives of Contrasting Schools. Educational Management Administration \& Leadership, 41(5), 620-639. DOI: 10.1177/1741143213488377

Vygotsky, L. S. (1978). Mind in Society: The development of higher psychological processes. Cambridge: Harvard University Press.

Wilson, V. (2014). Examining teacher education through cultural historical activity theory. Teacher Advancement Network Journal, 6(1), 20-29. 